\title{
Dried Cassava Residue in Laying Quail Feeding
}

http://dx.doi.org/10.1590/1806-9061-2019-1189

-Author(s)

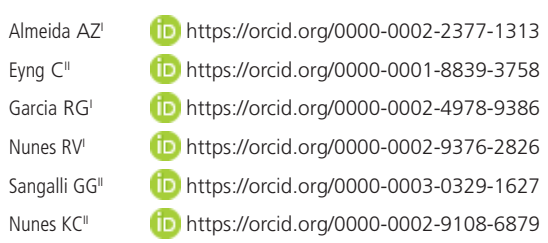

Universidade Federal da Grande Dourados. Universidade Estadual do Oeste do Paraná.

\section{nMail Address}

Corresponding author e-mail address Cinthia Eyng

Universidade Estadual do Oeste do Paraná - Centro de Ciências Agrárias - Rua Pernambuco, 1777 - Centro Marechal Cândido Rondon Paraná 85960000 Brazil. Phone: 4532547912

Email: cinthiaeyng@hotmail.com

\section{EKeywords}

Alternative feedstuff, Coturnix coturnix japonica, fiber.

\section{ABSTRACT}

This study evaluated the performance, egg quality, relative weight of the gastrointestinal organs, and the intestinal morphometry of laying quails fed diets containing levels of dried cassava residue (DCR). A total of 120 150-day-old Japanese quails were distributed in a completely randomized design with five treatments $(0.0 ; 2.5 ; 5.0 ; 7.5$; and $10.0 \%$ of $D C R$ ), four replicates, and six birds per experimental unit. The dietary inclusion of DCR did not affect ( $p>0.05$ ) performance, internal egg quality, yolk color, and the values of villus height, crypt depth, and villus height/crypt depth ratio for the segments of the small intestine. However, a linear increase $(p<0.05)$ was found for eggshell thickness, relative weight of the gizzard, and small intestine with increased dietary levels of the residue. For the relative weight of the pancreas, a quadratic effect $(p<0.05)$ was observed, with the lower relative weight estimated at $4.04 \%$ DCR inclusion. Comparing to the control group (0\% of DRC inclusion) the quails fed $5 \%$ of DRC showed a lower relative weight of the pancreas. The inclusion of up to $10 \%$ of dried cassava residue in laying quail's diets does not interfere with the performance. Among the organs of gastrointestinal tract, the inclusion of dried cassava residue increased the relative weight of gizzard and small intestine. In addition, it improves eggshell quality by increasing eggshell thickness.

\section{INTRODUCTION}

Quail farming has increased considerably in recent years. From the productive point of view, its advantages include small size, short life cycle, rapid growth, high fecundity and reproductive potential and shorter incubation time compared to other production birds (EL-Katcha et al., 2015).

The most commonly used energy source in quail farming is corn starch, an ingredient that competes directly with the human food system. Among the alternative energy sources available, the use of byproducts from the processing of cassava (Manihot esculenta Crantz) has received increased interest from nutritionists due to its high production potential (Picoli et al., 2014). In fact, according to Fiorda et al. (2013) for each ton of processed root about $928.6 \mathrm{~kg}$ of residue is produced. However, the high moisture content impedes the use of cassava byproducts on a large scale, as it leads to fermentation and, consequently, a loss of nutritional quality. Dried cassava residue is the result of the dehydration of cassava starch residue, which has a dry matter content of approximately $90 \%$, this process aims to transform the wet mass, generating a viable by-product that can be used in animal feeding.

The dry cassava residue is composed of starch and fibrous material that was not extracted during its production, and has great chemical composition variability, which is dependent on the variety and origin 
of the plant, as well as the processing technique was submitted, among other factors (Pandey et al., 2000).

The addition of alternative fibrous feedstuffs in poultry diets can compromise animal performance due to antinutritional factors. DCR has high levels of non-starch polysaccharides that cannot be digested by birds, because their binding is resistant to hydrolysis in the gastrointestinal tract (Broch et al., 2017) making it difficult to use successfully in poultry diets (Morgan \& Choct, 2016). Nevertheless, according to Duarte et al. (2013), quails might be able to make better use of fibrous feedstuffs when compared to broilers due to the morphophysiological characteristics of their gastrointestinal tract, enabling quails to have a more efficient digestibility. The larger relative size of the cecum compared to other birds species is probably responsible for the better utilization of the energy originating from fiber by quails (Silva Júnior et al., 2017).

Considering the above, this study aimed to evaluate the effects of feeding increasing levels of DCR on performance, relative weight of gastrointestinal organs, intestinal morphometry, and egg quality of Japanese quails.

\section{MATERIALS AND METHODS}

The trial was conducted at the Poultry Research Center of the Federal University of Grande Dourados UFGD, MS, Brazil, during a period of 84 days, divided into four cycles of 21 days each. The Ethics and Biosafety Committee of the UFGD approved this study under the protocol n. 029/2014 - CEUA/UFGD. A total of 120 150-day-old Japanese quails were housed in galvanized cages $(32 \times 33 \times 17 \mathrm{~cm})$, and each battery cage was fitted with nipple drinkers and metal feeders. A 17-hour-per-day light program was used $(12 \mathrm{~h}$ of natural light $+5 \mathrm{~h}$ of artificial light). The birds were distributed in a completely randomized design with five treatments $(0.0,2.5,5.0,7.5$, and $10.0 \%$ of dried cassava residue - DCR), four replicates, and six birds per experimental unit.

The cassava starch factory residue was composed of fibrous material and starch that was not extracted during processing, and was obtained from an agroindustrial cooperative in the region of Toledo, Paraná State, Brazil, air dried in a covered place with temperatures ranging from 23.4 to $28.5^{\circ} \mathrm{C}$ and relative humidity of $73.1 \%$. The material was revolved three times a day for a period of $7 \mathrm{~d}$.
The DCR chemical composition was composed of $89.86 \%$ dry matter, $60.73 \%$ starch, $0.31 \%$ ether extract, $1.12 \%$ crude protein, $13.57 \%$ crude fiber, $20.82 \%$ acid detergent fiber, $38.22 \%$ neutral detergent fiber, $1.53 \%$ mineral matter, and 1,703 $\mathrm{kcal} \mathrm{kg}^{1}$ apparent metabolizable energy. The analyzes were carried out at the Laboratory of Animal Nutrition of the State University of Western Paraná (Unioeste), and the metabolism assay was conducted at the Laboratory of Poultry Physiology and Metabolism, using broilers.

The experimental diets were formulated based on corn and soybean meal, considering the nutritional requirements for laying Japanese quails recommended by Rostagno et al. (2011) (Table 1). The experimental diets and water were supplied ad libitum.

To evaluate bird performance, the egg production was recorded daily to determine the hen-day egg production. On the 21 st day of each cycle, the feed was weighed to evaluate feed intake ( $\mathrm{g} / \mathrm{bird} / \mathrm{day})$ and feed conversion ( $\mathrm{kg}$ feed/ $\mathrm{kg}$ egg and $\mathrm{kg}$ feed/doz. egg).

Five days before the end of each cycle, all eggs produced by each experimental unit were collected during two consecutive days to evaluate egg yolk color. The analysis was performed using a Konica Minolta digital colorimeter, model CR-400. The following parameters were determined: L* (lightness - dark to light) and $b$ * (yellow/blue), all expressed in the CIELAB system.

During the last three days of each cycle, all eggs produced by each experimental unit were weighed to determine the mean weight. Subsequently, the specific gravity was evaluated by immersion of the eggs in saline solutions of different concentrations (1.050, $1.055,1.060,1.065,1.070,1.075,1.080,1.085$, and $1.090 \mathrm{~g} / \mathrm{mL}$ ). The saline solutions were adjusted and calibrated periodically with the aid of a hydrometer.

After determining the specific gravity, the eggs were broken on a flat surface and the height of the albumen and the height and diameter of the yolk were measured using digital calipers. The Haugh unit, based on the height of the albumen and egg weight, was calculated as described by Brant \& Shrader (1958). The yolk index was obtained as the ratio between the height and diameter of the yolk.

The eggshells were washed under running water without the removal of the inner membrane, dried at room temperature for 72 hours, and weighed on a precision scale to determine the percentage in relation to the egg weight. The evaluation of the eggshell thickness was performed using a digital caliper. 
Table 1 - Ingredients and nutrient composition of the experimental diets.

\begin{tabular}{|c|c|c|c|c|c|}
\hline \multirow[t]{2}{*}{ Ingredients (\%) } & \multicolumn{5}{|c|}{ Levels of inclusion of DCR (\%) } \\
\hline & 0.0 & 2.5 & 5.0 & 7.5 & 10.0 \\
\hline Corn & 55.03 & 50.85 & 46.67 & 42.49 & 38.31 \\
\hline Soybean meal (45\%) & 33.74 & 34.50 & 35.25 & 36.01 & 36.76 \\
\hline Limestone & 7.20 & 7.20 & 7.20 & 7.19 & 7.19 \\
\hline Dicalcium phosphate & 1.17 & 1.17 & 1.17 & 1.18 & 1.18 \\
\hline Dried cassava residue & 0.00 & 2.50 & 5.00 & 7.50 & 10.00 \\
\hline Soybean oil & 1.77 & 2.70 & 3.64 & 4.57 & 5.51 \\
\hline $\mathrm{NaCl}$ & 0.346 & 0.347 & 0.349 & 0.351 & 0.350 \\
\hline Supplement mineral and vitamin ${ }^{1}$ & 0.250 & 0.250 & 0.250 & 0.250 & 0.250 \\
\hline DL-Met (98\%) & 0.354 & 0.358 & 0.361 & 0.365 & 0.369 \\
\hline L-Lys HCl $(78.5 \%)$ & 0.144 & 0.129 & 0.114 & 0.099 & 0.084 \\
\hline \multicolumn{6}{|l|}{ Calculated composition } \\
\hline ME (Kcal kg-1) & 2800 & 2800 & 2800 & 2800 & 2800 \\
\hline Crude Fiber (\%) & 2.74 & 3.05 & 3.35 & 3.66 & 3.97 \\
\hline Crude Protein (\%) & 19.94 & 19.94 & 19.94 & 19.94 & 19.94 \\
\hline Dig Lys (\%) & 1.083 & 1.083 & 1.083 & 1.083 & 1.083 \\
\hline Dig Met + Cys (\%) & 0.888 & 0.888 & 0.888 & 0.888 & 0.888 \\
\hline Dig Thr (\%) & 0.678 & 0.678 & 0.679 & 0.680 & 0.680 \\
\hline Calcium (\%) & 3.099 & 3.099 & 3.099 & 3.099 & 3.099 \\
\hline Av Phosphorus (\%) & 0.323 & 0.323 & 0.323 & 0.323 & 0.323 \\
\hline Sodium (\%) & 0.155 & 0.155 & 0.155 & 0.155 & 0.155 \\
\hline
\end{tabular}

'Supplement mineral and vitaminic (content/kg of supplement): folic acid $80 \mathrm{mg}$; pantothenic acid 2200 mg; cooper $3600 \mathrm{mg}$; choline $40 \mathrm{mg}$; iron $18 \mathrm{mg}$; butylated toluene hydroxide 150 mg; iodine 300 mg; manganese 30 g; niacin 6000 mg; selenium 120 mg; vitamin A 2800000 Ul; vitamin B, 340 mg; vitamin B 2800 cg; vitamin B, 1000 mg; vitamin B6 560 mg; vitamin D 600000 Ul; vitamin E 2000 Ul; vitamin K 480 mg; zinc $28 \mathrm{~g}$.

At the end of the last cycle, two birds per replicate were selected and slaughtered by cervical dislocation to determine the relative weight (\% of live weight) of the gastrointestinal organs (proventriculus, gizzard, small intestine, large intestine, pancreas, and liver), the length of the small and large intestine (in which the rectum and the right- and left-sided cecum were considered). In addition, fragment sampling (duodenum, jejunum and ileum) was performed for analysis of the intestinal morphometry by light microscopy.

For the morphometric analyses, 2-cm fragments from each segment were opened longitudinally, washed with saline solution, fixed in buffered formalin solution $(10 \%)$, dehydrated in a series of alcohols of increasing concentration, diaphanized in xylol, and embedded in paraffin (Luna, 1968). After the semi-seriate histological cuts (sections of $7 \mu \mathrm{m}$ ), the sections were stained with hematoxylin and eosin. Morphometric analyses (30 readings/sample) were performed using Motic Image Plus 2.0. Villus height was measured from the apical to the basal region, which corresponded to the superior portion of the crypts. Crypts were measured from the basis to the region of transition between the crypt and the villus. Consequently, the villus height/crypt depth ratio was obtained.

The data relative to $D C R$ levels were examined using analysis of variance followed by Dunnett's test and polynomial regression by decomposition of the degrees of freedom, considering a significance of $p<0.05$. For all analyses, the statistical program ASSISTAT 7.7 Beta was used.

\section{RESULTS AND DISCUSSION}

The inclusion of DCR at different levels did not affect ( $p>0.05)$ the performance of quails. The performance of quails fed different levels of DCR did not differ ( $p>0.05)$ from those of quails in the control group ( $0 \%$ of DRC inclusion) (Dunnett's test) (Table 2).

The performance results corroborate with those found by Güçlü et al. (2004), who used other fibrous foods in Japanese quail feed, and did not find interference in the productive performance. Studies conducted by Esonu et al. (2010) and Duarte et al. (2013) demonstrate an increase in feed intake in broilers and quails, respectively, when fibrous ingredients were used. According to the authors, such results can be explained because fiber is considered a diluent of the diet.

In studies performed by Sundu et al. (2006), evaluating the performance of early-stage broilers fed diets containing coconut meal, a fibrous ingredient, a linear reduction in feed intake was observed. According to the authors, the high crude fiber content can alter 
Table 2 - Feed intake, hen-day egg production and feed conversion of laying quails fed diets containing different levels of dried cassava residue (DCR).

\begin{tabular}{lcccc}
\hline DCR (\%) & Feed intake (g/bird/day) & Hen-day egg production (\%) & Feed conversion (kg feed/kg egg) & Feed conversion (kg/doz. egg) \\
\hline 0.0 & 24.89 & 93.91 & 2.438 & 0.315 \\
\hline 2.5 & 24.45 & 95.30 & 2.439 & 0.308 \\
5.0 & 24.76 & 91.53 & 2.514 & 0.321 \\
7.5 & 24.15 & 93.10 & 2.445 & 0.313 \\
10.0 & 24.15 & 96.07 & 2.307 & 0.302 \\
\hline CV (\%) & 7.15 & 4.79 & 8.01 & 8.19 \\
\hline p Dunnett & 0.96 & 0.64 & 0.67 & 0.87 \\
\hline p Linear & 0.53 & 0.77 & 0.42 & 0.62 \\
\hline p Quadratic & 0.99 & 0.33 & 0.26 & 0.57 \\
\hline
\end{tabular}

$\mathrm{CV}=$ coefficient of variation

diet density, becoming a limiting factor in feed intake due to the space occupied in the digestive tract. As it can be observed, the feed intake of fibrous diets in poultry is controversial, which can be explained because fiber solubility has a different effect on the gastrointestinal tract. The soluble fiber has antinutritional properties, reducing the digestibility of proteins, carbohydrates and fats and reducing the metabolizable energy of the diet, causing an increase in feed conversion (Williams et al., 1997). On the other hand, insoluble fiber is associated with a higher passage rate and a reduced nutrient use (Krás et al., 2013).

The possible negative interference of fiber intake with animal performance may have been alleviated because the presence of this nutrient in the gastrointestinal tract increases the peristaltic movements and the production of endogenous enzymes (Mateos et al., 2012). In addition, it increases the gizzard, which may have resulted in efficient nutrient digestion. Furthermore, Duarte et al. (2013) suggest that quails may be able to make better use of fibrous feedstuffs when compared to broiler chickens due to the morphophysiological characteristics of their gastrointestinal tract, which favor higher digestibility, such as the higher passage rate in the digestive tract.
Increasing levels of DCR did not affect ( $p>0.05)$ internal egg quality and yolk color in quails. However, there was a linear increase $(p<0.05)$ in eggshell thickness with increased levels of the residue. However, when each inclusion dose of DCR was compared with the control treatment, no difference $(p>0.05)$ was observed (Table 3).

The improvement in eggshell thickness may be related with the increase in the relative weight of the gizzard, evidenced in the present study, associated with increased dietary fiber. This may be the result of a longer retention time of this nutrient in the organ (González-Alvarado et al., 2007) as well as increased peristaltic movements and production of endogenous enzymes (Mateos et al., 2012). Furthermore, a welldeveloped proventriculus and gizzard improve $\mathrm{HCl}$ secretion, thus enhancing the action of pepsin on the digesta in the stomach. Consequently, the solubility of the mineral fraction and the protein digestibility, among other components of the diet, are improved (Gabriel et al., 2003). Due to an increase in the absorption and availability of calcium, changes in the external egg quality may occur when high-fiber diets are fed. Consequently, the deposition of this mineral in the eggshell is altered, increasing its thickness.

Table 3 - External and internal egg quality and egg yolk color of laying quails fed diets containing different levels of dried cassava residue (DCR).

\begin{tabular}{lcccccccc}
\hline DCR $(\%)$ & $\begin{array}{c}\text { Egg Weight } \\
(\mathrm{g})\end{array}$ & $\begin{array}{c}\text { Haugh } \\
\text { Unit }\end{array}$ & $\begin{array}{c}\text { Egg Specific Gravity } \\
\left(\mathrm{g} / \mathrm{cm}^{3)}\right.\end{array}$ & $\begin{array}{c}\text { Egg Yolk } \\
\text { Index }\end{array}$ & $\begin{array}{c}\text { Egg Shell Ratio } \\
(\%)\end{array}$ & $\begin{array}{c}\text { Egg Shell Thickness } \\
(\mathrm{mm})\end{array}$ & $\begin{array}{c}\text { Luminosity } \\
\text { Yellowness } \\
(* \mathrm{~b})\end{array}$ \\
\hline 0.0 & 10.78 & 86.26 & 1.078 & 0.461 & 8.17 & 0.202 & 54.08 & 41.80 \\
2.5 & 10.51 & 87.20 & 1.078 & 0.468 & 8.07 & 0.203 & 53.57 & 42.38 \\
5.0 & 10.66 & 86.73 & 1.079 & 0.471 & 8.24 & 0.205 & 54.34 & 41.75 \\
\hline 7.5 & 10.66 & 87.08 & 1.079 & 0.474 & 8.19 & 0.206 & 53.87 & 41.88 \\
10.0 & 10.91 & 86.19 & 1.080 & 0.465 & 8.31 & 0.207 & 54.33 & 41.76 \\
\hline CV (\%) & 3.08 & 1.72 & 0.15 & 2.33 & 2.55 & 1.59 & 1.93 \\
\hline p Dunnett & 0.51 & 0.82 & 0.28 & 0.47 & 0.60 & 0.19 & 0.81 \\
\hline p Linear & 0.45 & 0.91 & 0.07 & 0.36 & 0.25 & 0.02 & 0.91 \\
\hline p Quadratic & 0.16 & 0.32 & 0.35 & 0.13 & 0.55 & 0.75 & 0.45 \\
\hline
\end{tabular}

${ }^{1} Y=0.20181251+0.00053472 x ; R^{2}=0.97 ; C V=$ coefficient of variation. 
In relation to the yolk color, according to Laudadio et al. (2014) this may be related to the amount of natural pigments contained in the alternative foods. Silva et al. (2019) observed a linear reduction in the $b$ * value in the breast meat and chick feet of broilers fed diets containing up to $10 \%$ of DRC, indicating a lower intensity of the yellow color, probably due the low concentration of carotenoids and xanthophylls in cassava. However, in the present study the amounts of dietary pigments did not interfere with the color of the yolk, even at the highest level of inclusion of DCR.

A quadratic effect $(p<0.05)$ was observed in the relative weight of the pancreas, with the lower relative weight estimated at $4.04 \%$ DCR inclusion. In addition, there was a linear increase $(p<0.05)$ for the relative weight of the gizzard and the small intestine with increased dietary levels of the residue. Comparing to the control group the quails fed $5 \%$ of DRC showed a lower relative weight of pancreas (Table 4).
The increase in the relative weight of the gizzard may be related to increased fiber levels, demonstrating a longer retention time of this nutrient in the organ due to the presence of particles of different sizes and characteristics, providing a greater grinding capacity for nutrient digestion (González-Alvarado et al., 2007). In addition, the presence of soluble fibers may cause an increase in gizzard size because its water retention ability leads to the swelling of the gizzard contents (Hernández et al., 2011). This greater gizzard development improves $\mathrm{HCl}$ secretion, thus intensifying the action of pepsin on the digesta in the proventriculus. Consequently, the solubility of the mineral fraction and the protein digestibility, among other components of the diet, can be improved (Gabriel et al., 2003).

The quadratic behavior observed in the relative weight of the pancreas corroborates that found by Duarte et al. (2013), evaluating soybean hulls in quail

Table 4 - Relative weight ( $\mathrm{g} / 100 \mathrm{~g}$ live weight) of gastrointestinal organs and lenght of small and large intestine (cm) of laying quails fed diets containing different levels of dried cassava residue (DCR).

\begin{tabular}{lcccccccc}
\hline DCR (\%) & Proventriculus & Gizzard & Pancreas & Liver & Small Intestine & Large Intestine & $\begin{array}{c}\text { Small Intestine } \\
\text { Lenght }\end{array}$ & $\begin{array}{c}\text { Large Intestine } \\
\text { Lenght }\end{array}$ \\
\hline 0.0 & 0.447 & 1.988 & 0.297 & 4.284 & 2.468 & 0.773 & 52.00 & 24.05 \\
2.5 & 0.480 & 2.006 & 0.280 & 3.908 & 2.952 & 0.801 & 51.05 & 23.85 \\
5.0 & 0.385 & 2.146 & $0.239^{*}$ & 3.861 & 2.957 & 0.770 & 53.35 & 22.90 \\
\hline 7.5 & 0.473 & 2.170 & 0.309 & 3.529 & 2.909 & 0.794 & 50.05 & 24.23 \\
10.0 & 0.518 & 2.192 & 0.343 & 3.702 & 3.228 & 0.838 & 53.25 & 23.13 \\
\hline CV (\%) & 14.20 & 7.46 & 8.33 & 20.73 & 12.35 & 10.25 & 7.38 & 4.83 \\
\hline p Dunnett & 0.11 & 0.25 & 0.0005 & 0.74 & 0.10 & 0.77 & 0.70 & 0.41 \\
\hline p Linear & 0.21 & $0.03^{1}$ & 0.007 & 0.24 & $0.02^{3}$ & 0.36 & 0.81 & 0.43 \\
\hline p Quadratic & 0.11 & 0.72 & $0.0002^{2}$ & 0.59 & 0.58 & 0.57 & 0.71 & 0.83 \\
\hline
\end{tabular}

$\mathrm{CV}=$ coefficient of variation

* Indicates a significant difference between control group and experimental group (Dunnett's test).

$1 Y=1.98639245+0.02285591 x ; R^{2}=0.89$

${ }^{2} Y=0.29718787+0.0194 x-0.0024 x^{2} ; R^{2}=0.87 ;$ minimum point: 4.04

${ }^{3} Y=2.6077+0.059 x ; R^{2}=0.28$

diets, which may be associated with the fiber levels tested. The hydration capacity and the abrasive effect of the fibrous compounds may cause, among other factors, the limitation of the endogenous enzymatic action on the substrates, triggering morphological and physiological changes in the gastrointestinal tract (Mateos et al., 2012).

The inclusion of the residue resulted in a linear increase in the relative weight of the small intestine. Dietary fiber changes may include an adaptive increase in the mass of the intestinal wall, cell proliferation rate, and intestinal muscle thickness (Svihus et al., 2010), which will lead to a greater weight of the small and large intestines.
The different levels of the residue did not change ( $p>0.05)$ the values of villus height, crypt depth, and villus height/crypt depth in the small intestine segments. Differences in intestinal morphometric were not detected ( $p>0.05)$ between the groups receiving DRC and the control group (Table 5).

The inclusion of fiber can alter the characteristics of the intestinal villi, modifying the effects of the diet on animal performance. Dysfunctions and lesions caused by mechanical agents, such as the abrasive effect of the fibers, can cause an imbalance in turnover, with a consequent decrease in villus height, increase in cell synthesis, migration and extrusion, and a decrease in the digestive capacity and the absorption of the 
Table 5 - Villus height $(\mu \mathrm{m})$, crypt depth $(\mu \mathrm{m})$, and villus height/crypt depth ratio $(\mathrm{V}: \mathrm{C})$ of the small intestine segments of laying quails fed diets containing different levels of dried cassava residue (DCR).

\begin{tabular}{|c|c|c|c|c|c|c|c|c|c|}
\hline \multirow[b]{2}{*}{ DCR (\%) } & \multicolumn{3}{|c|}{ Duodenum } & \multicolumn{3}{|c|}{ Jejunum } & \multicolumn{3}{|c|}{ Ileum } \\
\hline & $\begin{array}{l}\text { Villus } \\
\text { Height }\end{array}$ & Crypt Depth & $V: C$ & $\begin{array}{l}\text { Villus } \\
\text { Height }\end{array}$ & Crypt Depth & $\mathrm{V}: \mathrm{C}$ & $\begin{array}{l}\text { Villus } \\
\text { Height }\end{array}$ & $\begin{array}{l}\text { Crypt } \\
\text { Depth }\end{array}$ & $\mathrm{V}: \mathrm{C}$ \\
\hline 0.0 & 802.12 & 45.07 & 17.81 & 350.83 & 34.47 & 10.15 & 295.59 & 31.67 & 9.20 \\
\hline 2.5 & 704.17 & 41.82 & 17.15 & 317.95 & 35.06 & 9.10 & 288.00 & 32.56 & 8.75 \\
\hline 5.0 & 702.45 & 45.71 & 15.43 & 378.09 & 35.96 & 10.54 & 354.82 & 33.98 & 10.50 \\
\hline 7.5 & 671.48 & 46.38 & 14.33 & 356.73 & 34.54 & 10.36 & 329.92 & 32.89 & 10.06 \\
\hline 10.0 & 731.43 & 45.68 & 15.09 & 324.44 & 34.73 & 9.37 & 324.22 & 32.78 & 9.88 \\
\hline CV (\%) & 15.11 & 11.97 & 14.43 & 20.95 & 7.70 & 20.25 & 23.28 & 8.60 & 20.33 \\
\hline P Dunnett & 0.69 & 0.10 & 0.98 & 0.74 & 0.80 & 0.60 & 0.68 & 0.52 & 0.66 \\
\hline $\mathrm{p}$ Linear & 0.33 & 0.19 & 0.30 & 1.00 & 1.00 & 0.92 & 0.45 & 0.65 & 0.44 \\
\hline p Quadratic & 0.18 & 0.45 & 0.43 & 0.56 & 0.55 & 0.70 & 0.53 & 0.42 & 0.65 \\
\hline
\end{tabular}

$\mathrm{CV}=$ coefficient of variation

mucosa (Wils-Plotz \& Dilger, 2013). Moreover, the presence of highly viscous digesta in the intestinal lumen may increase the rate of cell loss, leading to villous atrophy and crypt hyperplasia (Montagne et al., 2003), impairing the intestinal absorption capacity.

According to Rahmatnejad \& Saki (2016), the capacity of the intestine to absorb nutrients is proportional to the number of villi, and the reduction of villus size results in a decreased intestinal absorption efficiency. Complementary, Montagne et al. (2003) reported that the villus/crypt ratio indicates the digestive capacity of the small intestine. An increase in this ratio represents an improvement in digestion and absorption. Therefore, there was no compromise in the integrity of the intestinal epithelium in the different segments of the small intestine with the use of the different levels of the residue, which explains the productive performance parameters found in the present study.

\section{CONCLUSION}

The inclusion of up to $10 \%$ of dried cassava residue in laying quail diets does not interfere with the performance. Among the organs of the gastrointestinal tract, the inclusion of dried cassava residue increased the relative weight of the gizzard and small intestine. In addition, it improves eggshell quality by increasing eggshell thickness.

\section{REFERENCES}

Brant AW, Shrader HL. Equipment and methods for measuring egg quality [Agricultural Marketing Service, 246]. Washington: Department of Agriculture;1958.

Broch J, Nunes RV, Oliveira V, Silva IM, Souza C, Wachholz L. Dry residue of cassava as a supplementation in broiler feed with or without addition of carbohyrases. Semina: Ciências Agrárias 2017;38(4):2641-2658.
Duarte CRA, Murakami AE, De Mello KS, Picoli KP, Garcia AFQM, Ferreira MFZ. Soybean hulls in quail diets. Semina: Ciências Agrárias 2013;34(6):3057-3068

El-Katcha MI, Soltan M, Ramdan SS, El Naggar MK, El-Shobokshy SA. Growth Performance, Blood biochemical changes, carcass traits and nutrient digestibility of growing japanese quail fed on various dietary Protein and calcium levels. Alexandria Journal of Veterinary Science 2015;44(1):38-53.

Esonu BO, Iheshiulor O, Chukwuka O, Omede A, Ogbuewu I. Performance characteristics and haematology of laying birds fed Safzyme supplemented soybean hull diet. Report and Opinion 2010;2(8):16-21.

Fiorda FA, Soares Júnior MS, Silva FA, Souto LRF, Grossmann MVE. Farinha de bagaço de mandioca: aproveitamento de subproduto e comparação com fécula de mandioca. Pesquisa Agropecuária Tropical 2013;43:408416.

Gabriel I, Mallet S, Leconte M. Differences in the digestive tract characteristics of broiler chickens fed on complete pelleted diet or on whole wheat added to pelleted protein concentrate. British Poultry Science 2003;44(2):283-290.

González-Alvarado JM, Jiménez-Moreno, Lázaro R, Mateos GG. Effect of type of cereal, heat processing of the cereal, and inclusion of fiber in the diet on productive performance and digestive traits of broilers. Poultry Science 2007;86(8):1705-1715.

Hernández F, López MJ, García, V, Martínez, S, Megías MD, Madrid J. Influence of cereal type and the inclusion of sunflower meal as a source of additional dietary fibre on nutrient retention, growth performance and digestive organ size in broilers from one to twenty-one days of age. Animal Feed Science and Technology 2011;165(3-4):251-257.

Güçlü BK, Iscan KM, Uyanik F, Eren M, Agca AC. Effect of alfalfa meal in diets of laying quails on performance, egg quality and some serum parameters. Archives of Animal Nutrition 2004;58(3):255-263.

Krás RV, Kessler ADM, Ribeiro AML, Henn JD, Bockor L, Sbrissia AF. Effect of dietary fiber, genetic strain and age on the digestive metabolism of broiler chickens. Revista Brasileira de Ciência Avícola 2013;15(2):83-90.

Laudadio V, Ceci E, Lastella NMB, Introna M, Tufarelli V. Low-fiber alfalfa (Medicago sativa L.) meal in the laying hen diet: Effects on productive traits and egg quality. Poultry Science 2014;93(7):1868-1874.

Luna LG. Manual of histologic staining methods of the Armed Forces Institute of Pathology. New York : Blakiston Division, McGraw-Hill;1968.

Mateos GG, Jiménez-Moreno E, Serrano MP, Lázaro RP. Poultry response to high levels of dietary fiber sources varying in physical and chemical 
characteristics. Journal of Applied and Poultry Research 2012;21(1):156174.

Montagne L, Pluske JR, Hampson DJ. A review of interactions between dietary fibre and the intestinal mucosa, and their consequences on digestive health in young non-ruminant animals. Animal Feed Science and Technology 2003;108(1-4):95-117.

Morgan NK, Choct M. Cassava: nutrient composition and nutritive value in poultry diets. Animal Nutrition 2016;2(4):253-261.

Picoli KP, Murakami AE, Nunes RV, Duarte CRA, Eyng C, Ospina-Rojas IC. Cassava starch factory residues in the diet of slow-growing broilers. Tropical Animal Health and Production 2014;46(8):1371-1381.

Pandey A, Soccol CR, Nigam P. Biotechnological potencial of agroindustrial residue II: cassava bagasse. Bioresource Technology 2000;74(1):81-87.

Rahmatnejad E, Saki AA. Effect of dietary fibres on small intestine histomorphology and lipid metabolism in young broiler chickens. Journal of Animal Physiology and Animal Nutrition 2016;100(4):665672.

Rostagno HS, Albino LFT, Donzele JL, Gomes PC, Oliveira RF, Lopes DC, et al. Tabelas brasileiras para aves e suínos: composição de alimentos e exigências nutricionais. $3^{\text {rd }}$ ed. Viçosa: UFV/DZO; 2011.
Silva IM, Broch J, Wachholz L, de Souza, C, Dalolio FS, Teixeira LV, et al. Dry residue of cassava associated with carbohydrases in diets for broiler chickens. The Journal of Applied Poultry Science 2019;28(4):11891201.

Silva Júnior PA, Lana SRV, Lana GRQ, Silva LCL, Torres EC, Ferreira TS. Cassava foliage in quail feeding. Acta Veterinária Brasilica 2017;11:150-156.

Sundu B, Kumar A, Dingle J. Response of broiler fed increasing levels of copra meal and enzymes. International Journal of Poultry Science 2006;5(1):13 -18.

Svihus B, Sacranie A, Choct M. The effect of intermittent feeding and dietary whole wheat on performance and digestive adaptation in broiler chickens. Poultry Science 2010;89(12):2617-2625.

Williams PEV, Geraert PA, Uzu G, Annison G. Factors affecting nonstarch polysaccharide digestibility in poultry. CIHEAM-Options Mediterraneeannes 1997;26:125-134.

Wils-Plotz EL, Dilger RN. Combined dietary effects of supplemental threonine and purified fiber on growth performance and intestinal health of young chicks. Poultry Science 2013;92(3):726-734. 